DOI: $10.24326 /$ fmpmsa.2017.57

\title{
THE POSSIBILITY OF MAIZE STRAW APPLICATION AS A SUBSTRATE FOR BIOGAS PLANTS
}

\author{
Jacek PRZYBYŁ, Jacek DACH, Dawid WOJCIESZAK, Jakub MAZURKIEWICZ, \\ Maciej ZABOROWICZ \\ Poznan University of Life Sciences, POLAND \\ E-mail of corresponding author: jacek.przybyl@up.poznan.pl
}

Keywords: maize straw, substrate, biogas production

\begin{abstract}
The maize straw has a huge energetic potential. In Poland, the maize straw harvest can reach almost 5 million ha per year. With the good perspective for biogas market development in Poland, maize straw can become a good, reasonable substrate for biogas plant and avoid the conflict between food and biofuels production. This paper presents the potential for maize straw used as substrate for biogas plants. The results show that maize straw can be more effective for biogas productivity than maize silage. For 3 kinds of maize straw silage (from 4 analysed in total) the results of methane production were significantly higher $\left(120.14-141.73 \mathrm{~m}^{3} / \mathrm{Mg} \mathrm{FM}\right)$ than in case of typical maize silage biomethane efficiency.
\end{abstract}

\section{INTRODUCTION}

In the last two decades, the development of renewable energy sources (RES) has been observed worldwide. Although renewable energy has been produced for more than a hundred years by hydroelectric plants, but it has only been since the 1990s that wind energy has spread, and after 2000 photovoltaics also. The prices of electricity produced by wind turbines or photovoltaic panels are falling successively and after 2020 the cost of generating the electricity from these installations will be lower than that of coal-fired power plants. The problem, however, is the instability of electricity produced from wind or sun. Photovoltaic panels, although unstable, are predictable during the 24-hour period (this is related to the movement of the sun in the sky). Moreover, an active change of their position relative to the sun can be used in order to increase their efficiency (Bugała et al., 2016a, Bugała et al., 2016b).

An alternative to fossil fuels and unstable RES is biogas production (Czekała et al., 2015; Pohl et al., 2012). It should be emphasized, that Poland is European leader in the development of modern biogas technologies, although the total number of installations does not exceed 300 (including 95 agricultural biogas plants - August 2017). The best Polish biogas plants work with real efficiency close to theoretical one, which diametrically differentiates them from wind power plants (efficiency $22-25 \%$, off-shore at the sea up to $45 \%$ ) or especially from photovoltaic installations (efficiency 10-16\%). For example, the agricultural biogas plant in Jaromierz (Fig. 1) with the $1 \mathrm{MW}$ of electric power, in 2016 produced $8499.5 \mathrm{MWh}$, which means efficiency at the level of $97 \%$ of theoretical efficiency.

What is also exceptional in Polish biogas plants (technologies Dynamic Biogas or ProBioGas) - it is the potential for fermentation of very large spectrum of substrates from agronomy and biowaste from agro-industrial sector. This increases the profitability of modern biogas plants because traditionally, those installations had to use mainly silages (i.e. German biogas sector uses every year over $60 \mathrm{mln}$ tonnes of maize silage). 


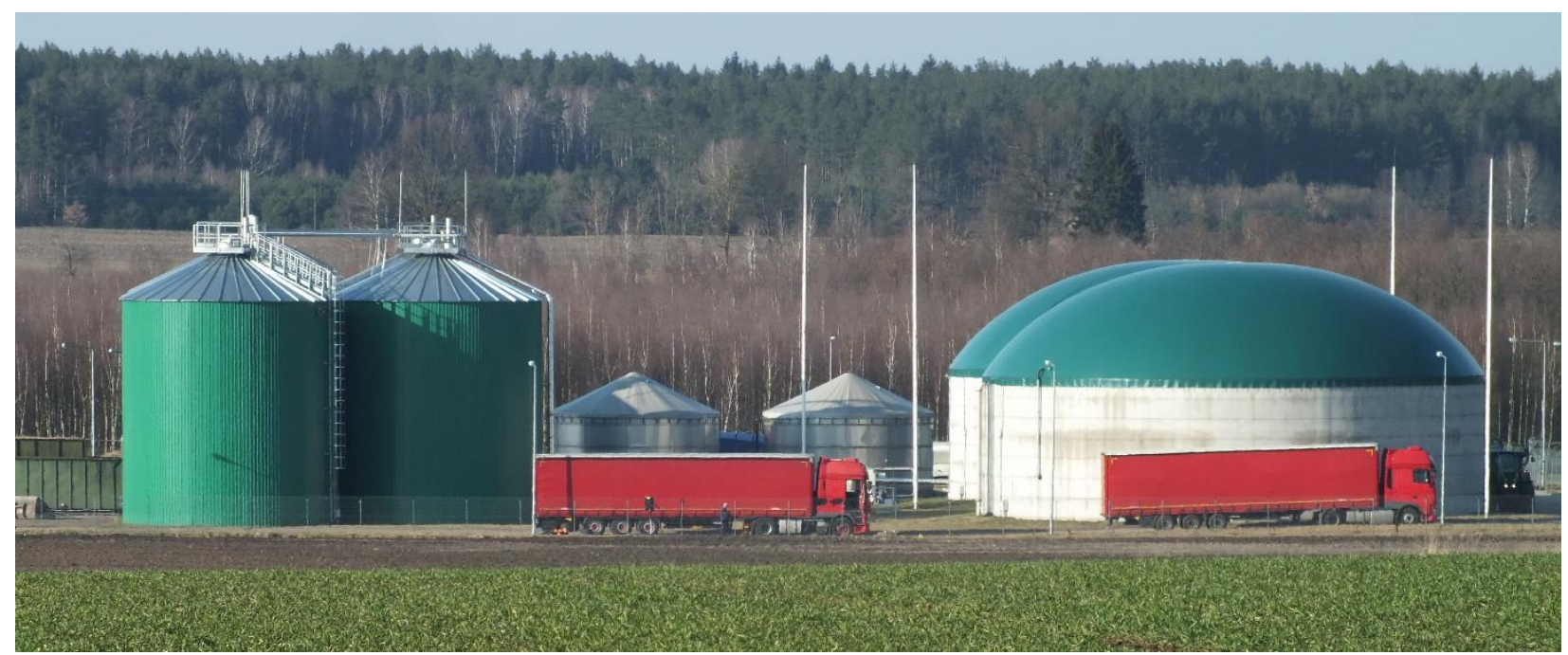

Fig. 1. Agricultural biogas plant (Dynamic Biogas technology) in Jaromierz

One of the most commonly used raw materials for biogas production are energy crops: maize silage, sunflower silage, cereal silage (Dach et al., 2014). In Europe, biomass from energy crops has a 35-40\% share of substrate mixtures used in biogas plants (Rive et al., 2014; Cerbin et al., 2012). High yield of biogas from energy crops allows them to be widely used in high power biogas plants ( $>1 \mathrm{MW})$. On the other hand, the raw material from energy crops accounts for 35-40\% of the total cost of biogas production (Schievano et al., 2015), so that their use for biogas production is not profitable (Croce et al., 2016) and is not compatible with the principles of sustainable development. Moreover, the use of energy crops to produce biogas creates a conflict between food production and energy production (Croce et al., 2016). This is why sustainable biogas production can play a key role in the ongoing fight against global warming and climate change.

The method to reduce the cost of biogas production and its sustainable production is the use of substrates that are residues from agricultural production (Czekała et al., 2017). Recently, much attention is paid to lignin-cellulose waste materials. They are widely available and the purchase cost is low (Ferreira et al., 2014). Talebnia et al. (2010) show that lignin-cellulose waste is the largest source of raw material for energy production by anaerobic digestion. Agriculture can play a special role in providing lignin-cellulose substrates for biogas production, such as cereal straw, maize straw or rice straw. Since their cost is not high, their use is part of the sustainable production of biogas (Chandra et al., 2012a, b, c).

In the past ten years, worldwide, it has been observed $40 \%$ increase in maize grain production, which is currently 1030 million tonnes. In the European Union, total maize grain production in 2016 was 60.3 million tonnes and increased by 1.8 million tonnes in comparison with 2015 [Menardo et al. 2015, USDA 2016]. In Poland, maize grain production in 2015 was 3.16 million tonnes [CSO 2016]. That is why maize straw can be an easily accessible substrate for agricultural biogas plants (Zbytek et al., 2016). World production of maize straw is estimated at 230 million $\mathrm{Mg}$. The highest amount of 150 million $\mathrm{Mg}$ of maize 
straw is produced in America, while in Asia it is 45 million $\mathrm{Mg}$, in Europe 31 million $\mathrm{Mg}$, in Africa 3.5 million $\mathrm{Mg}$ and 0.5 million $\mathrm{Mg}$ in Australia (Najafi et al., 2008).

The aim of this study is to analyze the possibility of maize straw using as a substrate for biogas plants, especially taking into account the most popular substrate in Europe -the maize - as a reference point. In order to estimate better the potential of maize straw application for biogas plant sector, different kinds of straw silage (with large spectrum of dry matter content) have been tested.

\section{MATERIAL AND METHODS}

\section{Tested material}

The substrate for methane fermentation was silage from maize straw. We have analyzed 4 type of maize straw silages with completely different content of dry mass:

- $\quad$ CCS1: $31.35 \%$ of dry mass content;

- $\quad$ CCS2: $39.50 \%$ of dry mass content;

- $\quad$ CCS3: 62.90 of dry mass content;

- $\quad$ CCS4: $78.88 \%$ of dry mass content.

CCS1 silage was made of straw after harvest of Ambrosini maize variety from KWS company with FAO 220, stay green type. Harvested biomass contained 33\% of dry matter. The yield of maize dry mass consisted of $53 \%$ of the flasks, $24 \%$ of the stem, $15 \%$ of the leaves and $8 \%$ of the flasks cover leaves. The maize straw was harvested by a field chopper with theoretical cutting length $20 \mathrm{~mm}$. The straw was ensilaged in a flexible silo with length of $60 \mathrm{~m}$.

The CCS2 silage was prepared from the straw directly after harvesting the maize grain PR39A79 from Pioneer with FAO 300. The dry matter content of the residue was $68 \%$ and dry matter content amounted $87.11 \%$. The yield of maize dry matter consisted of $59 \%$ of flasks, $19 \%$ of stems, $14 \%$ of leaves and $8 \%$ of flasks cover leaves. The CCS2 silage was made up in a cylindrical bale wrapped in foil, CSS3 silage in elastic silo and CCS4 silage in a field prism covered with foil. The straw harvest was executed using New Holland 644 variable-compaction press and Pöttinger Jumbo 7200 Powermatic pickup truck.

\section{Biogas research methodology}

The maize straw samples were analyzed in Laboratory of Ecotechnologies at the Institute of Biosystems Engineering (PULS) - the biggest Polish biogas laboratory. The biogas efficiency analyzes were made according to German DIN 38414/S8 and VDI 4630 procedures - standard methods used in most of European countries. The final results were expressed in normal cubic meter per $1 \mathrm{Mg}$ of fresh mass (FM), dry mass (DM) or organic dry mass $(\mathrm{ODM})$ of the substrates $\left(\mathrm{m}^{3} / \mathrm{Mg} \mathrm{FM}\right)$. Before biogas analysis procedures, the samples were checked for dry mass and organic dry mass content within Polish Norms (PN75 C-04616/01) and (PN-Z-15011-3).

The results obtained in this maize straw experiment were compared with the biogas efficiency of typical maize silage in order to analyze the energetic and economic usage of maize straw as the substrate for biogas production (Cieślik et al., 2016). 


\section{RESULTS}

Maize straw silage of CCS1 had dry mass of $31.35 \%$, and in visual and organoleptic evaluation it had a very similar appearance and smell to the typical maize silage from the whole plants (fig.1). In CCS1 silage the content of lactic acid amounted 1.08\%, which was the largest content compared to other silages.

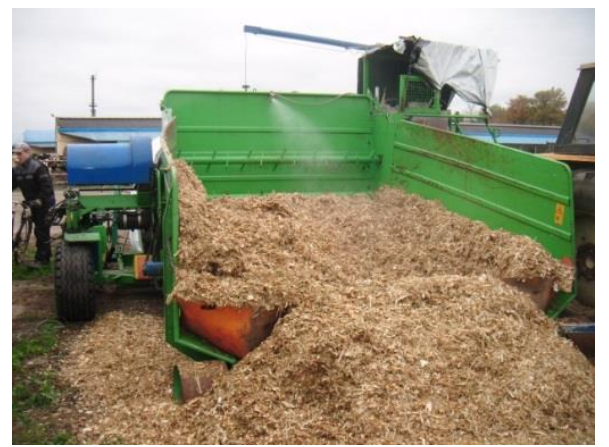

Fig. 1. Maize straw silage CCS1 had look and smell similar to typical maize silage

CCS4 silage had dry mass of $78.88 \%$ and in the visual and organoleptic assessment, it had crushed odor and was covered with mycelium. Between the tested silage - CCS4 contained the lowest level of lactic acid $(0.17 \%)$ and acetic acid $(0.2 \%)$.

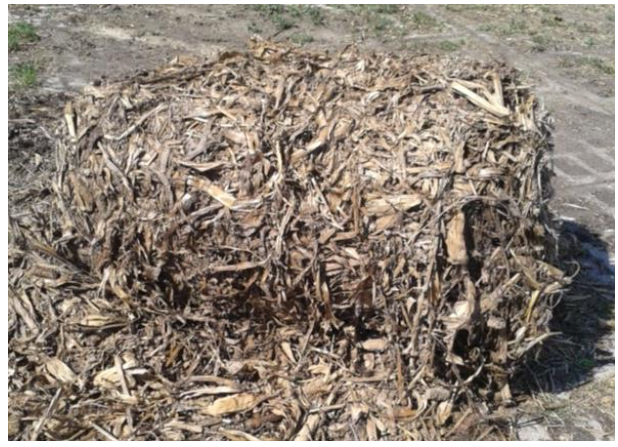

Fig. 2. Maize straw silage CCS4 had look and smell comparable to composted material

Moreover, the analysis of $\mathrm{pH}$ has shown the big difference between the materials. The silage with the highest humidity had the lowest $\mathrm{pH}$ (3.95), however in contrary CCS4 $(78.88 \%$ of dry mass) had pH over 6 (Tab. 1).

Tab. 1. Level of $\mathrm{pH}$ and concentration of Volatile Fatty Acids in analyzed silages

\begin{tabular}{|l|c|c|c|c|}
\hline \multirow{2}{*}{$\begin{array}{c}\text { Maize straw } \\
\text { ensilaged }\end{array}$} & \multirow{2}{*}{$\mathrm{pH}$} & \multicolumn{3}{|c|}{ Volatile Fatty Acids [\%] } \\
\cline { 3 - 5 } & & Lactic acid & Acetic acid & Butyric acid \\
\hline CCS1 & 3.95 & 1.08 & 0.61 & 0.07 \\
\hline CCS2 & 4.91 & 0.29 & 0.51 & 0.42 \\
\hline CCS3 & 4.52 & 1.07 & 0.68 & 0.03 \\
\hline CCS4 & 6.06 & 0.17 & 0.20 & 0.24 \\
\hline
\end{tabular}

Analyzing the results of biogas productivities, for biogas plant holders, the most important is amount of methane produced from $1 \mathrm{Mg}$ of substrate fresh matter. From this point of view, the best result was obtained for CCS3 material - $141.73 \mathrm{~m}^{3}$ of $\mathrm{CH}_{4}$ per $\mathrm{Mg}$ (Tab. 2). This is almost $40 \mathrm{~m}^{3}$ more than in case of typical maize silage (app. $102 \mathrm{~m}^{3} / \mathrm{Mg}$ ). In case of 3 examined maize straw silages the methane productivity was higher than for typical maize 
silage. Only the most wet material (CCS1) had significantly lower methane productivity $\left(59.68 \mathrm{~m}^{3} / \mathrm{Mg}\right)$ than maize silage.

Furthermore, the obtained results show that more dry silages (CCS3 and CCS4) have higher biomethane productivity from fresh mass, which seems to be favorable for typical field conditions during harvesting period (usually maize straw has dry mass content over 50\%).

Tab. 2. Biogas and methane yield from $1 \mathrm{Mg}$ of tested material

\begin{tabular}{|c|c|c|c|c|c|c|c|c|c|}
\hline \multirow[t]{2}{*}{ Substrate } & \multirow{2}{*}{$\begin{array}{c}\mathrm{TS} \\
{[\%]}\end{array}$} & \multirow{2}{*}{$\begin{array}{l}\text { LOI } \\
{[\% \text { TS }]}\end{array}$} & \multicolumn{3}{|c|}{$\begin{array}{c}\text { Cumulative biogas yield } \\
{\left[\mathrm{m}^{3} / \mathrm{Mg}\right]}\end{array}$} & \multirow{2}{*}{$\begin{array}{c}\text { Methane } \\
\text { concentration } \\
{[\%]}\end{array}$} & \multicolumn{3}{|c|}{$\begin{array}{l}\text { Cumulative methane yield } \\
\qquad\left[\mathrm{m}^{3} / \mathrm{Mg}\right]\end{array}$} \\
\hline & & & FM & TS & ODM & & FM & TS & ODM \\
\hline $\mathrm{C}$ & 31.35 & 017 & & & & 47.98 & 59 & & \\
\hline & & & & & & & & & 5.41 \\
\hline $\mathrm{CC}$ & & & & & & & & & 244.81 \\
\hline CCS4 & 78.88 & 92.40 & 239.23 & 303.28 & 337.39 & 56.13 & 139.60 & 176.98 & 196.89 \\
\hline
\end{tabular}

The cost of maize straw silage production (including harvest and transport) calculated for 6 different technologies within the project of the Ministry of Science 'The Technology of Harvesting and Storage of Maize Straw as an Energy Biomass and Structural Substrate for Composting" has started from $75 \mathrm{PLN} / \mathrm{Mg}$ of silage. This is clearly lower amount than in case of maize silage production (approximate cost - $110 \mathrm{PLN} / \mathrm{Mg}$ ). It shows that maize straw silage can be much better substrate for biogas plant comparing with typical maize silage because of lower production costs and significantly higher biomethane productivity from 1 $\mathrm{Mg}$ of fresh mass.

\section{CONCLUSIONS}

1. The performed research experiments have showed the big difference in physic-chemical parameters between analyzed maize straw silages.

2. Except the material with the highest moisture (CCS1), all analyzed maize straw silages have clearly higher methane productivity from $1 \mathrm{Mg}$ of fresh mass than typical maize silage. This causes that silages made from maize straw are very attractive substrate for biogas production.

3. In comparison with typical maize silage, maize straw silage can be much more effective substrate for biogas production due to lower production costs and significantly higher biomethane productivity from $1 \mathrm{Mg}$ of fresh mass.

\section{REFERENCES}

Bugała A., Frydrychowicz-Jastrzębska G., Zbytek Z., Dach J., Janczak D. (2016b). Long - term performance evaluation of a fixed and solar follow - up systems with modified astronomical positioning in Polish conditions. MATEC Web of Conferences 59, 03004 DOI: 10.1051/matecconf/20165903004

Bugała A., Jastrzębska G., Janczak D., Dach J., Boniecki P. (2016a). The influence of the wavelength and intensity of solar radiation on the power characteristics generated by the photovoltaic modules in tracking system. Energy and Clean Technologies Conference Proceedings, SGEM 2016, VOL III: 337-344.

Cerbin S., Nowakowski K., Dach J., Pilarski K., Boniecki P., Przybyl J., Lewicki A., 2012 Possibilities of neural image analysis implementation in monitoring of microalgae production as a substrate for biogas plant. $4^{\text {th }}$ International Conference on Digital Image Processing (ICDIP 2012). Proceedings of SPIE. Vol.: 8334 Article Number: 83342A Doi: 10.1117/12.954164 
Chandra R., Takeuchi H., Hasegawa T., (2012a). Hydrothermal pretreatment of rice straw biomass: a potential and promising method for enhanced methane production. Appl. Energy 94, 129-140.

Chandra R., Takeuchi H., Hasegawa T., Kumar R., (2012c). Improving biodegradability and biogas production of wheat straw substrates using sodium hydroxide and hydrothermal pretreatments. Energy 43, 273-282.

Chandra, R., Takeuchi H., Hasegawa T., (2012b). Methane production from lignocellulosic agricultural crop wastes: a review in context to second generation of biofuel production. Renew. Sust. Energ. Rev. 16, 14621476 .

Cieślik M., J. Dach, Lewicki A., Smurzyńska A., Janczak D., Pawlicka-Kaczorowska J., Boniecki P., Cyplik P., Czekała W., Jóźwiakowski K. 2016 Methane fermentation of the maize straw silage under meso- and thermophilic conditions. Energy 115 (2), 1495-1502.

Croce S., Wei Q., D'Imporzano G., Dong R., Adani F. (2016). Anaerobic digestion of straw and corn stover: The effect of biological process optimization and pre-treatment on total bio-methane yield and energy performance. Biotechnology Advances 34, 1289-1304.

CSO (2016). Agriculture in 2015. Warsaw.

Czekała, W., Dach, J., Czekała, J. (2015). Operational possibilities of a biogas plant at the brewery under polish conditions. Proceedings of the 2nd International Conference on Energy \& Environment: Bringing Together Engineering and Economics: 520-525.

Czekała, W., Dach, J., Dong, R., Janczak, D., Malińska, K., Jóźwiakowski, K., Smurzyńska, A., Cieślik, M. (2017). Composting potential of the solid fraction of digested pulp produced by a biogas plant. Biosystems Engineering 160, 25-29.

Dach J., Boniecki P., Przybył J., Janczak D., Lewicki A., Czekała W., Witaszek K., Rodríguez Carmona P. C., Cieślik M. (2014). Energetic efficiency analysis of the agricultural biogas plant in $250 \mathrm{kWe}$ experimental installation. Energy 69, 34-38. doi:10.1016/j.energy.2014.02.013

Ferreira L.C., Nilsen P.J., Fdz-Polanco F., Pérez-Elvira S.I. (2014). Biomethane potential of wheat straw: influence of particle size, water impregnation and thermal hydrolysis. Chem. Eng. J. 242, 254-259.

Menardo S., Airoldi G., Cacciatore V., Balsari P. (2015). Potential biogas and methane yield of maize stover fractions and evaluation of some possible stover harvest chains. Biosystems Engineering 129, 352-359.

Najafi, G., Ghobadian, B., Tavakoli, T., Yusaf, T. (20080. Potential of bioethanol production from agricultural wastes in Iran. Renew. Sust. Energ. Rev. 13, 1418-1427.

Pohl M., Mumme J., Heeg K., Nettmann E. (2012). Thermo- and mesophilic anaerobic digestion of wheat straw by the upflow anaerobic solid-state (UASS) process. Bioresour. Technol. 124, 321-327.

Riva C., Schievano A., D'Imporzano G., Adani F. (2014). Production costs and operative margins in electric energy generation from biogas. Full-scale case studies. Waste Manag. 34, 1429-1435.

USDA. Grain: World Markets and Trade. Foreign Agricultural Service, November 2016.

Zbytek Z., Dach J., Pawłowski T., Smurzyńska A., Czekała W., Janczak D. (2016). Energy and economic potential of maize straw used for biofuels production. MATEC Web of Conferences 60, 04008. DOI: $10.1051 /$ matecconf/20166004008 